Milos Poliak - Juraj Hammer - Kelvin Cheu - Marek Jaskiewicz*

\title{
IDENTIFICATION OF COSTS STRUCTURE CHANGE IN ROAD TRANSPORT COMPANIES
}

The costs of each company on the market are an essential component of financial decision making, not only on the price of the goods and services provided, but also about the business efficiency. In business, services have a significant impact on pricing, but also for deciding on the realization of performances. Costs structure is composed of fixed and variable costs. Changing the costs structure creates assumptions for other decisions, as well as the pricing of the entrepreneur. The goal of this article was to identify, whether there is a change in time of the costs structure.

Keywords: costs, freight transport, transport companies, business

\section{Introduction}

Pricing in the road freight transport, with regard to the provision of services, in a liberalized market in terms of price, is not regulated by the prescribed tariffs or pricing processes [1] The price for transportation is decided only by agreement between the carrier and the shipper. Given this fact, the carrier must know the real costs that arise at him in providing of services, as a prerequisite for the agreement of the shipping costs. If the costs structure changes over time that would affect the price change of the realized performance. If one assumes that the carrier has created the two basic costs group - fixed and variable costs, their share would affect the development of the transport price. At a higher share of the fixed costs, the growth rate of total costs slows down, but there would be growth of realized costs [2]. However, the overall costs decrease more slowly when the performance declines, which reduces the competitiveness of the entrepreneur, because the price depends on the total costs [2]. The objective of this article was to identify whether there is a change in time of the costs structure, assuming that the price change option is influenced by the changing performance in time periods.

\section{Analysis of current costs situation in transport companies}

Considering that pricing in the road freight transport is liberalized, every carrier can come to the market with its own pricing policy. From this perspective, the following factors can be identified affecting the price of transport:

- Vehicle size and dimensions;

- Options of recovery transportation (demand impact);

- Unladen driving (empty ride);

- Referral availability and other services;
- Road and traffic conditions;

- Price input factor (work, vehicle, spare parts and fuel);

- Quality of management [3].

Based on output by Korzhenevych et al. [3], it is possible to define the share of individual costs, featured in Table 1.

Another factor, influencing pricing, is related to the maintenance of the rolling stock, analysed by Drozdiel a Piasecki [4]. Based on those author's outputs, it is possible to state, that the fleet is more economically efficient if prescribed maintenance is carried out.

\subsection{Impact of costs structure on costs calculation by variable and fixed costs}

There are currently several calculation methods, which however cannot be used economically to calculate the price in the road transport, since that is a service area. The aim of this part of the paper is to highlight the reality that the cost structure affects the price of realized services. Output of costs calculation, with their division into the variable and fixed parts, are the following price rates [5]:

- Per kilometer with cargo,

- For one hour of the vehicle's operation.

This calculation specifically approaches the individual costs groups. The variable costs, which can be labelled as costs dependent on distance (e.g. toll costs, fuel costs, tire costs), arise only when the vehicle is moving; this means that they shall be incurred by the carrier only if he realizes the transportation. If the carrier is unable to provide the shipment, the costs would not arise [6-7].

The second group of costs are the fixed costs, which are dependent on time and arise regardless of whether the carrier carries out the transport or the vehicle is in downtime (e.g.

\footnotetext{
* ${ }^{1}$ Milos Poliak, ${ }^{1}$ Juraj Hammer, ${ }^{2}$ Kelvin Cheu, ${ }^{3}$ Marek Jaskiewicz

${ }^{1}$ IDepartment of Road and Urban Transport, Faculty of Operation and Economics of Transport and Communications, University of Zilina, Slovakia ${ }^{2}$ Department of Civil Engineering, The University of Texas at El Paso, USA

${ }^{3}$ Department of Automotive Vehicles and Transportation, Faculty of Mechatronics and Machine Engineering, Kielce University of Technology,

Poland

E-mail: milos.poliak@fpedas.uniza.sk
} 
Table 1 Typical share of transport costs for semi-trailers

\begin{tabular}{llr}
\hline & Cost item & $\begin{array}{c}\text { Share of operating } \\
\text { costs }(\%)\end{array}$ \\
\hline & Fuel & $20-30$ \\
Variable costs & Motor oil & $1-5$ \\
& Tires & $10-15$ \\
& Spare parts & $15-20$ \\
& Drivers - wages & $10-20$ \\
& Other work & 5 \\
& Depreciation and interest & $15-20$ \\
& Burden costs & $10-15$ \\
\hline
\end{tabular}

Table 2 Average costs item values of the transport companies between 2004 and 2017

\begin{tabular}{|c|c|c|c|c|c|c|c|c|c|c|c|c|}
\hline & $\begin{array}{c}\text { fuel } \\
(€ / \mathrm{km})\end{array}$ & $\begin{array}{c}\text { toll } \\
(€ / \mathrm{km})\end{array}$ & $\begin{array}{l}\text { tires } \\
(€ / \mathrm{km})\end{array}$ & $\begin{array}{c}\text { oil } \\
(€ / \mathrm{km})\end{array}$ & $\begin{array}{l}\text { driver's } \\
\text { wages } \\
(€ / \mathrm{km})\end{array}$ & $\begin{array}{l}\text { depreciation } \\
(€ / \mathrm{km})\end{array}$ & $\begin{array}{c}\text { repair } \\
\text { maintenance } \\
(€ / \mathrm{km})\end{array}$ & $\begin{array}{c}\text { motor } \\
\text { insurance } \\
(€ / \mathrm{km})\end{array}$ & $\begin{array}{l}\text { accident } \\
\text { insurance } \\
(€ / \mathrm{km})\end{array}$ & $\begin{array}{c}\text { motor } \\
\text { vehicle tax } \\
(€ / \mathrm{km})\end{array}$ & $\begin{array}{l}\text { burden }(€ / \\
\text { km) }\end{array}$ & $\underset{(€ / \mathrm{km})}{\sum_{(1)}}$ \\
\hline 2004 & 0.3142 & 0.063 & 0.02 & 0.00467 & 0.13 & 0.12 & 0.03 & 0.0155 & 0.016 & 0.015 & 0.012 & 0.74037 \\
\hline 2005 & 0.3253 & 0.063 & 0.021 & 0.00467 & 0.135 & 0.13 & 0.035 & 0.0155 & 0.017 & 0.015 & 0.013 & 0.77447 \\
\hline 2006 & 0.3498 & 0.063 & 0.022 & 0.0048 & 0.14 & 0.14 & 0.035 & 0.0155 & 0.017 & 0.015 & 0.014 & 0.8161 \\
\hline 2007 & 0.3587 & 0.066 & 0.023 & 0.005 & 0.15 & 0.14 & 0.04 & 0.0155 & 0.018 & 0.016 & 0.014 & 0.8462 \\
\hline 2008 & 0.3701 & 0.07 & 0.023 & 0.006 & 0.158 & 0.15 & 0.04 & 0.016 & 0.018 & 0.016 & 0.014 & 0.8811 \\
\hline 2009 & 0.3594 & 0.078 & 0.024 & 0.0088 & 0.16 & 0.16 & 0.05 & 0.016 & 0.02 & 0.017 & 0.015 & 0.9082 \\
\hline 2010 & 0.3627 & 0.1111 & 0.026 & 0.0125 & 0.165 & 0.165 & 0.054 & 0.016 & 0.02 & 0.017 & 0.0155 & 0.9648 \\
\hline 2011 & 0.3788 & 0.1158 & 0.028 & 0.0178 & 0.17 & 0.17 & 0.055 & 0.165 & 0.022 & 0.017 & 0.016 & 1.1554 \\
\hline 2012 & 0.3785 & 0.12 & 0.03 & 0.021 & 0.175 & 0.17 & 0.06 & 0.017 & 0.025 & 0.0175 & 0.016 & 1.03 \\
\hline 2013 & 0.3822 & 0.12 & 0.033 & 0.022 & 0.18 & 0.175 & 0.06 & 0.017 & 0.025 & 0.0198 & 0.0165 & 1.0505 \\
\hline 2014 & 0.3856 & 0.1242 & 0.038 & 0.024 & 0.185 & 0.18 & 0.065 & 0.0175 & 0.028 & 0.0198 & 0.017 & 1.0841 \\
\hline 2015 & 0.3874 & 0.1287 & 0.048 & 0.025 & 0.19 & 0.185 & 0.065 & 0.018 & 0.028 & 0.0198 & 0.0185 & 1.1134 \\
\hline 2016 & 0.3896 & 0.129 & 0.05 & 0.026 & 0.198 & 0.19 & 0.07 & 0.02 & 0.03 & 0.02 & 0.019 & 1.1416 \\
\hline 2017 & 0.3914 & 0.13 & 0.052 & 0.0265 & 0.2 & 0.19 & 0.074 & 0.02 & 0.03 & 0.0208 & 0.019 & 1.1537 \\
\hline
\end{tabular}

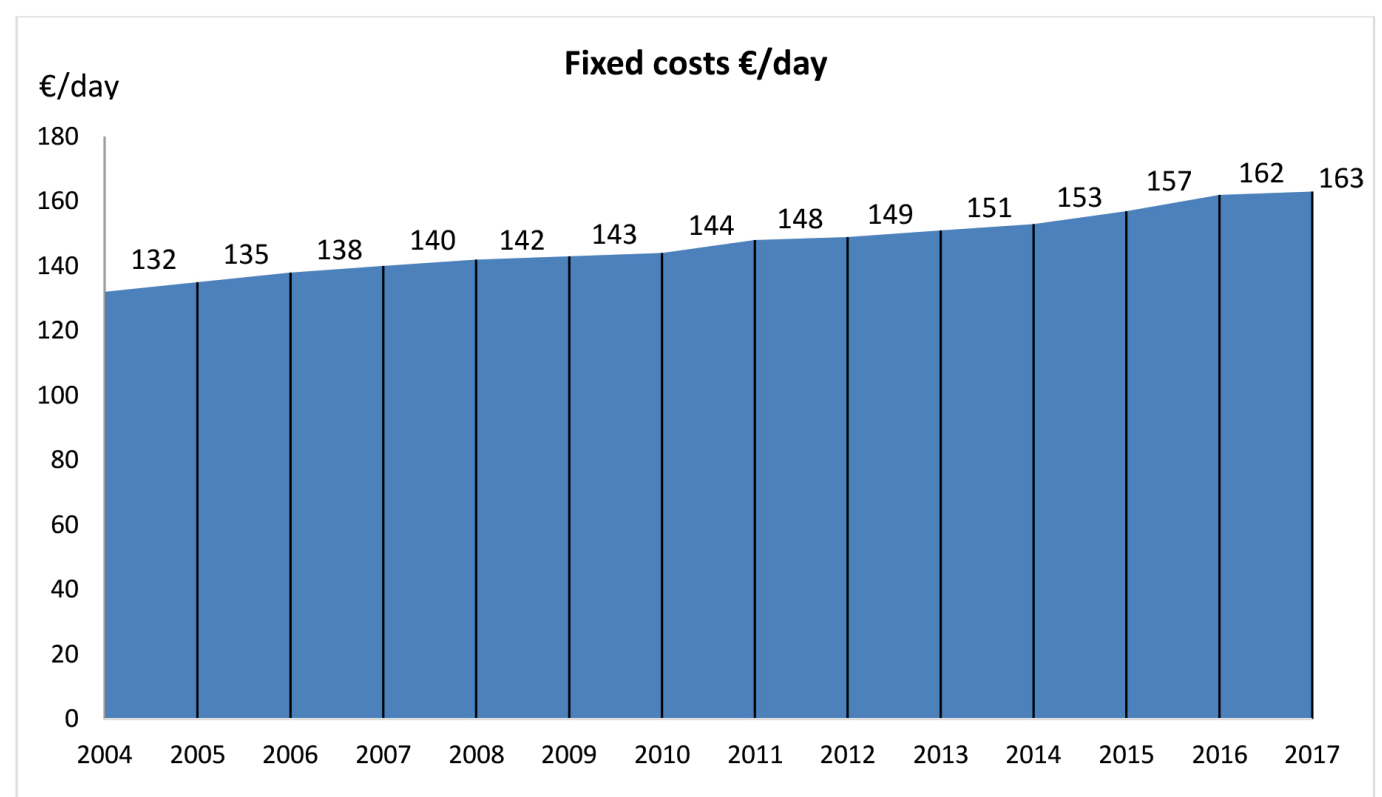

Figure 1 The course of fixed costs for transport companies between 2004 and 2017 per vehicle - semi-trailer 


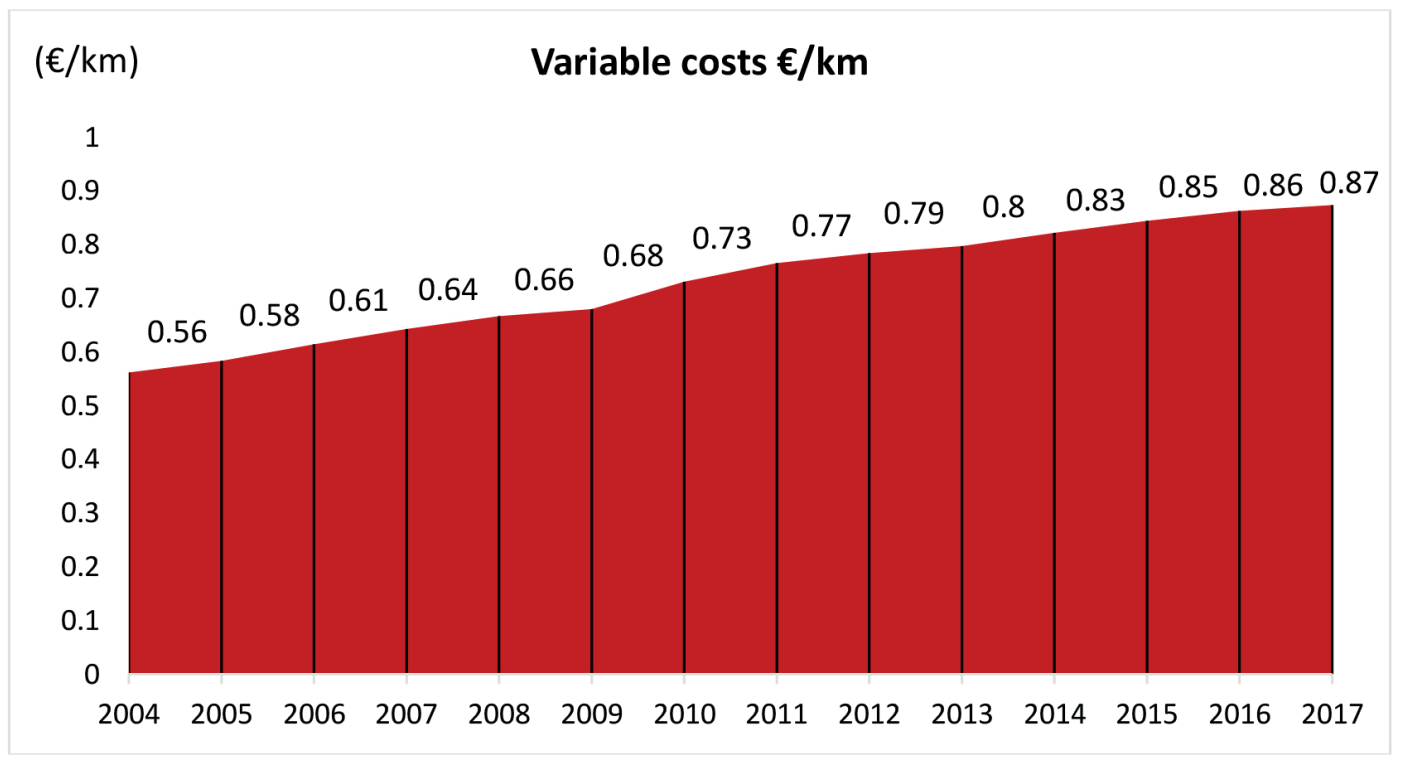

Figure 2 The course of variable costs for transport companies between 2004 and 2017

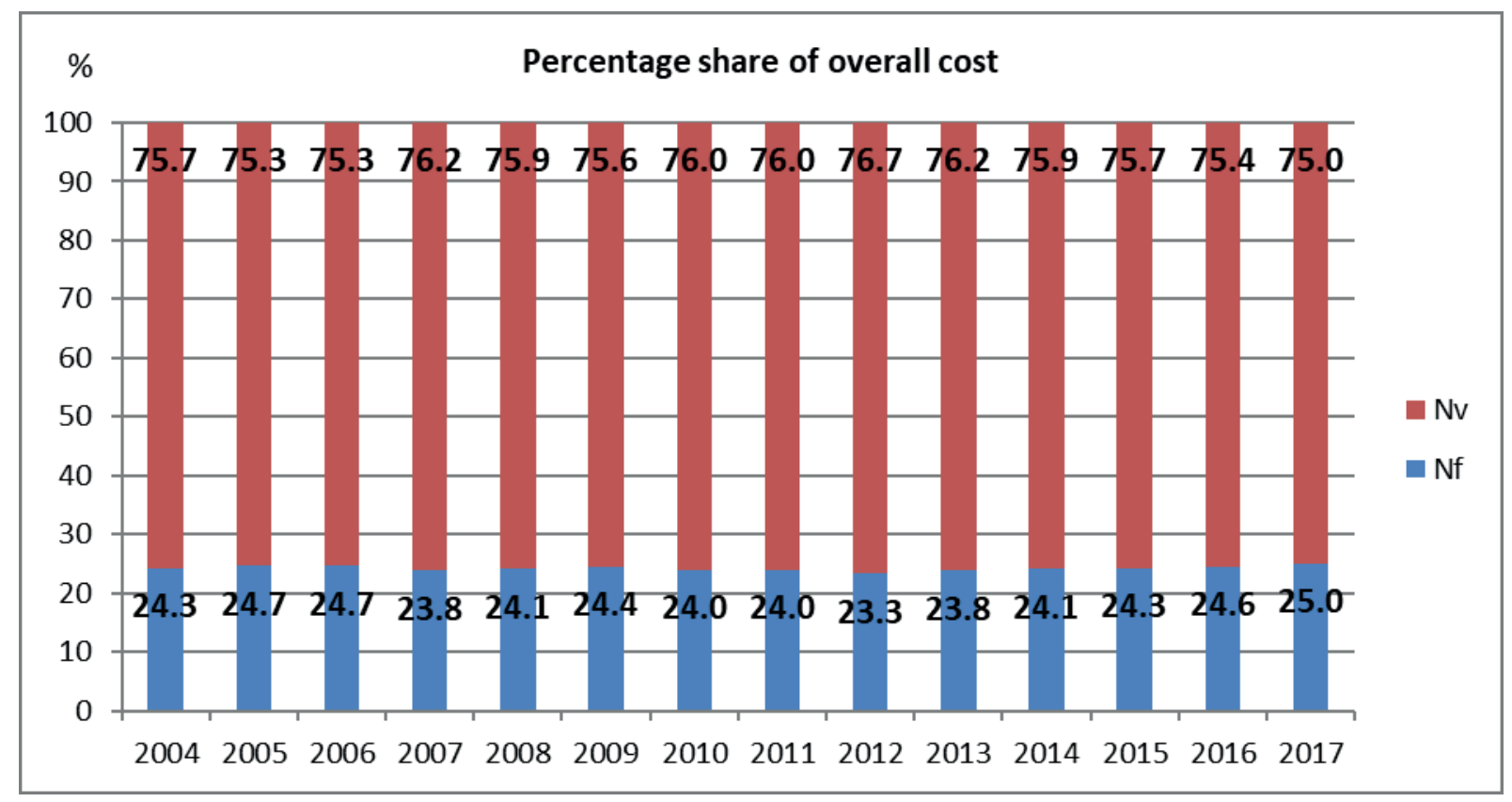

Figure 3 Expressing the structure of costs and their shares from 2004 to 2017

depreciation costs, vehicle insurance costs, the costs of motor vehicle tax) [8-9].

The principle of calculation is that per unit of realized power (e.g. km) variable costs are counted directly; the fixed costs expressed in time are converted into a calculation unit - the average speed, as follows [10-11]:

$n_{c}=\left(n_{\downarrow} / \beta\right)+\left(N / v_{t}\right)$,

where:

$n_{c}$ - total costs $(€)$,

$n_{v}$ - variable costs $(€ / \mathrm{km})$,

$\beta$ - driving utilization coefficient (\%),

$N_{f}$ - fixed costs $(€ / \mathrm{km})$,

$v_{t}$ - average speed $(\mathrm{km} / \mathrm{h})$.
The higher the proportion of the fixed costs in annual costs, then at higher performance are the higher level of overall costs, as well [12-13].

\subsection{Impact of the costs structure on price at dynamic costing}

Dynamic calculation is a costs calculation the output of which are the costs for performance [14-15]. In addition, the outputs of this costs calculation are dependent on the costs structure. The variable costs are set on a unit of realized performance, while the fixed costs are set for one day of vehicle operation. The total costs are set as the sum of the product of the unit of the variable costs and realized performance and the fixed costs per day of operation [16-18]. 
The fixed costs component of total costs for one day of operation is the same regardless of performance. The costs structure also has significant influence on pricing. With an increasing proportion of the fixed costs, the cost change becomes less flexible [19-20].

\section{Research on the costs structure change in the road freight transport}

In order to identify the change in the costs structure, costs need to be monitored for a longer period of time. At University of Zilina, a team of authors observed the cost of operating the vehicle, from 2004 to 2017, to identify change the costs structure. Costs were tracked across the multiple companies provided that they performed the fleet analysis. Costs were taken into account and statistical set only for the semi-trailers, weighing up to 40 tonnes with conversion to unit costs. Annual driving performance of one semi-trailer was about 100,000 kilometres with an average consumption of 30 litters per 100 kilometres [21]. Table 2 shows the average values for the transport companies in individual years. Table 2 is made over a span of 15 transport companies and their calculated cost items, who provided data for this research.

Authors divided the costs into two groups: the variable costs that are dependent on the distance travelled and the fixed costs that do not change based on distance travelled [22].

Fixed costs included depreciation, motor insurance, accidents' insurance, motor vehicle tax and burden. In Figure 1 the rising costs in transport companies can be observed in year-on-year comparisons [23]. In Figure 1, an increasing trend can be observed of the fixed costs, which has a uniformly rising character in year-on-year comparisons with a difference of about $5 \%$ increase costs per year.

The second costs group of the transport company are the variable costs, among which authors have included fuel, vignette, respectively toll, engine oil, repair and maintenance and driver wage [24].
In Figure 2 a development of the variable cost items in transport companies can be seen. It can be stated that the biggest increase was recorded in 2010 when the toll item has risen, due to introduction of this charging method of the freight transport in Slovakia. Until 2010, the freight was charged with a highway stamp.

Based on Table 2, the combined fixed and variable costs are graphically represented in Figure 3, in the year-on-year range.

From 2004 to 2017, both costs groups increased. In 2004, the fixed and variable costs totalled 0.7404 per kilometre. For 2017, this is already a sum of 1.1537 per kilometre, what means in an increase of $64 \%$ in 14 years period. Figure 3 shows that the costs structure lies year-on-year within range of $3 / 4$ for variable costs of the total costs and for the fixed costs of $1 / 4$ of the total costs in a transport company.

\section{Conclusion}

Based on a research conducted for a 14 year period in transport companies, the authors can state that there is very little change in the cost structure in road freight transport. For the identified period from 2004 to 2017, the fixed costs ratio was at the level of $25 \%$ of the total costs while $75 \%$ share belonged to the variable costs of operating vehicle. This research confirmed that, although the transport costs are increasing by the carriers in the 14 year period, the structure of their shares is changing only slightly and practically remains constant, which is good for planning calculation of economic efficiency of the transport company.

\section{Acknowledgements}

The contribution was realized with the support of the Ministry of Education of the Slovak Republic VEGA no. 1/0143/17 "Increasing the competitiveness of Slovak carriers providing road transport services in the common market of the European Union".

\section{References}

[1] POLIAK, M. The relationship with reasonable profit and risk in public passenger transport in the Slovakia. Ekonomicky casopis / Journal of Economics. 2013, 54(7), p. 668-684. ISSN 0013-3035.

[2] RIHA, Z., TICHY, J. The costs calculation and modelling in transport. 19th International Conference. Transport Means. 2015 : proceedings. 2015. ISSN 1822-296X, p. 388-391.

[3] KORZHENEVYCH, A., BROCKER, J. Spillovers of European regional investment subsidies: analysing using a forward-looking spatial GCE model. 2017.

[4] DROZDZIEL, P., PIASECKI, S. Study of the medthod of assessing the economic efficiency of exploitation cars in a transport company. Folia Societatis Scientiarum Lublinensis. 1995, p. 60-66. ISSN 1428-3646.

[5] BLENDON, R. BENSON, J. M., BRODIE, M., MORIN, R., ALTMAN, D. E., GITTERMAN, D., BROSSARD, M., JAMES, M. Bridging the gap between the public and economists views of the economy. Journal of Economic Perspectives. 1997, 11(3), p. $105-$ 118. ISSN 0895-3309, eISSN 1944-7965.

[6] GNAP, J., CAJCHAN, J., SULGAN, M. Measuring methodology form real bus-stop distances of mass passenger transport. Communications - Scientific Letters of the University of Zilina [online]. 2003, 5(3), p. 8-9. ISSN 1335-4205, eISSN 2585-7878. Available from: http://komunikacie.uniza.sk/index.php/communications/article/view/1355 
[7] LEWANDOWSKI, P. Attempts to protect the internal market for road transport in specific European Union countries. Zeszyty Naukowe Akademii Morskiej w Szczecinie / Scientific Journals Of the Maritime University of Szczecin [online]. 2016, 47, p. 141-146. ISSN 1733-8670, eISSN 2392-0378. Available from: https://doi.org/10.17402/161

[8] CYPRICH, O., KONECNY, V., KILIANOVA, K. Short-term passenger demand forecasting using univariate time series theory. Promet - Traffic\&Transportation, Scientific Journal on Traffic and Transportation Research. 2013, 25(6), p. 533-541. ISSN 0353-5320, eISSN 1848-4069.

[9] POLIAK, M., POLIAKOVA, A. Relation of social legislation in road transport on driver's work quality. 15th International Conference on Transport Systems Telematics TST 2015 : proceedings [online]. 2015, ISBN 978-3-319-24576-8, eISBN 978-3-31924577-5, p. 300-310. Available from: https://doi.org/10.1007/978-3-319-24577-5

[10] VUKOVIC, A. Units of account in international and domestic transport law (in Croatian). Nase More. 2013, 60(1-2), p. 11-16. ISSN 0469-6255, e-ISSN 1848-6320.

[11] GRAND, L., DURET, B. Differences in competitiveness and relocation of European freight companies. Transports. 2000, 400, p. 99.

[12] POLIAK, M., SEMANOVA, S., POLIAKOVA, A. Risk allocation in transport public service contracts. Ekonomski Pregled. 2015, 66(4), p. 384-403. ISSN 0424-7558, eISSN 1848-9494.

[13] ROTONDO, E. The legal effect of EU Regulations. Computer Law \& Security Review [online]. 2013, 29(4), p. 437-445. ISSN 02673649. Available from: https://doi.org/10.1016/j.clsr.2013.05.003

[14] RADIONOV, N. Limitation of liability right in road freight carriage in Croatia: an extinct institute. Uniform Law Review [online]. 2016, 21(4), p. 457-468. ISSN 1124-3694, eISSN 2050-9065. Available from: https://doi.org/10.1093/ulr/unw035

[15] LUBANSKI, N. Moving closer together - trade union europeanisation in the construction sector. Transfer: European Review of Labour and Research [online]. 2000, 6(1), p. 103-109. ISSN 1024-2589, eISSN 1996-7284. Available from: https://doi.org/10.1177/102425890000600110

[16] LORENC, A., KUZNAR, M. An intelligent system to predict risk and costs of cargo thefts in road transport. International Journal of Engineering and Technology Innovation [online]. 2018, 8(4), p. 284-293. ISSN 2223-5329, eISSN 2226-809X. Available from: http://ojs.imeti.org/index.php/IJETI/article/view/1013

[17] MUKHERJEE, A., ZHAO, L. Profitable parallel trade in unionized. Journal of Economics [online]. 2012, 107(3), p. 267-276. ISSN 0931-8658, eISSN 1617-7134. Available from: https://doi.org/10.1007/s00712-012-0267-7

[18] ZODROW, G. Tax competition and tax coordination in the European Union. International Tax and Public Finance [online]. 2003, 10(6), p. 651-671. ISSN 0927-5940, eISSN 1573-6970. Available from: https://doi.org/10.1023/A:1026377819946

[19] OSTERLOH, S., DEBUS, M. Partisan politics in corporate taxation. European Journal of Political Economy [online]. 2012, 28(2), p. 215-226. ISSN 0176-2680, eISSN 1873-5703. Available from: https://doi.org/10.1016/j.ejpoleco.2011.11.002

[20] EDWARDS, J., KEEN, M. Tax competition and Leviathan. European Economic Review [online]. 1996, 40(1), p.113-134. ISSN 0014-2921. Available from: https://doi.org/10.1016/0014-2921(95)00057-7

[21] LAI, Y. B. The political economy of capital market integration and tax competition. European Journal of Political Economy [online]. 2010, 26(4), p. 475-487. ISSN 0176-2680, eISSN 1873-5703. Available from: https://doi.org/10.1016/j.ejpoleco.2010.02.001

[22] BRENNAN, G., BUCHANAN, J. The power to tax: analytical foundations of a fiscal constitution. Cambridge UK: Cambridge University Press, 1980. ISBN 0521233291.

[23] JASKIEWICZ, M., WIECKOWSKI, D. The impact of the safety belt used for chairs used in buses and minibuses with small-speed collisions. Zeszyty Naukowe Akademii Morskiej w Szczecinie / Scientific Journals Of the Maritime University of Szczecin. 2014, 39(111), p. 78-81. ISSN 1733-8670, eISSN 2392-0378.

[24] POLIAK, M., HAMMER, J., REUTER, R., POLIAKOVA, A. The impact of the transport route on the cost of the transfer. 11th International Scientific and Technical Conference on Automotive Safety Location : proceedings [online]. 2018. ISBN 978-1-53864579-6. Available from: https://doi.org/ 10.1109/AUTOSAFE.2018.8373319 